\title{
Assia Djebar, Queste voci che mi assediano. Scrivere nella lingua dell'Altro
}

\section{Ilaria Vitali}

\section{(e) OpenEdition}

1 Journals

\section{Edizione digitale}

URL: http://journals.openedition.org/studifrancesi/30878

DOI: 10.4000/studifrancesi.30878

ISSN: 2421-5856

\section{Editore}

Rosenberg \& Sellier

\section{Edizione cartacea}

Data di pubblicazione: 1 avril 2006

Paginazione: 200

ISSN: 0039-2944

\section{Notizia bibliografica digitale}

Ilaria Vitali, «Assia Djebar, Queste voci che mi assediano. Scrivere nella lingua dell'Altro», Studi Francesi

[Online], 148 (XLX | I) | 2006, online dal 30 novembre 2015, consultato il 21 avril 2021. URL: http:// journals.openedition.org/studifrancesi/30878; DOI: https://doi.org/10.4000/studifrancesi.30878

Questo documento è stato generato automaticamente il 21 avril 2021.

\section{(c) (i) $\odot$}

Studi Francesi è distribuita con Licenza Creative Commons Attribuzione - Non commerciale - Non opere derivate 4.0 Internazionale. 


\section{Assia Djebar, Queste voci che mi assediano. Scrivere nella lingua dell'Altro}

Ilaria Vitali 
NOTIZIA

ASSIA DJEBAR, Queste voci che mi assediano. Scrivere nella lingua dell'Altro, Milano, Il

Saggiatore, 2004. Traduzione di Roberto Salvadori, pp. 250.

Questo importante saggio sulla creazione letteraria nell'universo francofono, a metà tra la riflessione critica e l'autentica opera narrativa, raggiunge il pubblico italiano nella traduzione di Roberto Salvadori. In una brillante prosa poetica, Djebar ricostruisce in quest'opera le tappe del suo percorso artistico, soffermandosi sugli eventi centrali del suo cammino di scrittrice. Primo fra tutti, la scelta del francese, lingua al tempo stesso amata e odiata, lingua dell'Altro, come suggerisce il sottotitolo del saggio nella sua versione italiana (nella versione francese, il sottotitolo, altrettanto significativo, era: "En marge de ma francophonie"). Lo studio è strutturato in sette parti, ognuna delle quali analizza un aspetto importante della creazione letteraria entre-deux. Oltre ad uno studio brillante, il saggio è la testimonianza di un percorso intellettuale, in cui le evocazioni dell'infanzia e l'approdo alla scrittura durante la guerra civile algerina, si mescolano ad una profonda riflessione sull'identità e sulla scrittura. Partendo dalla provocatoria domanda "Francofonia?", titolo della prima parte, Djebar si interessa via via alle particolarità della scrittura francofona al femminile, al tema dell'autobiografismo, alla scrittura della memoria, fino a volgere la sua riflessione alla scrittura dello straniero/straniera, il tutto a partire dalla propria opera. Un viaggio in sette tappe nei meandri della creazione letteraria entre-deux, guidato dalla voce limpida e coinvolgente di una grande scrittrice. 